\title{
Mesenchymal Stem Cells as a Bio Organ for Treatment of Female Infertility
}

\author{
Sahar Esfandyari ${ }^{1}$, Rishi Man Chugh ${ }^{1}$, Hang-soo Park ${ }^{1}$, Elie Hobeika ${ }^{2}$, Mara Ulin ${ }^{1}[$ [D and \\ Ayman Al-Hendy ${ }^{1,3, *}$ \\ 1 Department of Surgery, University of Illinois at Chicago, 820 South Wood Street, Chicago, IL 60612, USA; \\ sesfan2@uic.edu (S.E.); rmchugh@uic.edu (R.M.C.); hspark@uic.edu (H.-s.P.); mulin2@uic.edu (M.U.) \\ 2 Fertility Centers of Illinois, Glenview, IL 60026, USA; hobeika.elie.md@gmail.com \\ 3 Department of Obstetrics and Gynecology, University of Chicago, 5841 South Maryland Ave, \\ Chicago, IL 60637, USA \\ * Correspondence: aalhendy@bsd.uchicago.edu
}

Received: 8 September 2020; Accepted: 3 October 2020; Published: 8 October 2020

\begin{abstract}
Female infertility is a global medical condition that can be caused by various disorders of the reproductive system, including premature ovarian failure (POF), polycystic ovary syndrome (PCOS), endometriosis, Asherman syndrome, and preeclampsia. It affects the quality of life of both patients and couples. Mesenchymal stem cells (MSCs) have received increasing attention as a potential cell-based therapy, with several advantages over other cell sources, including greater abundance, fewer ethical considerations, and high capacity for self-renewal and differentiation. Clinical researchers have examined the therapeutic use of MSCs in female infertility. In this review, we discuss recent studies on the use of MSCs in various reproductive disorders that lead to infertility. We also describe the role of microRNAs (miRNAs) and exosomal miRNAs in controlling MSC gene expression and driving MSC therapeutic outcomes. The clinical application of MSCs holds great promise for the treatment of infertility or ovarian insufficiency, and to improve reproductive health for a significant number of women worldwide.
\end{abstract}

Keywords: infertility; mesenchymal stem cells (MSCs); reproductive system; stem-cell therapy

\section{Introduction}

Female infertility is defined as the inability to achieve any pregnancy after one year (or longer) (Hull, Glazener et al., 1985) [1]. Infertility affects millions of people worldwide and thus has received intense attention, with clinical/ researchers focused on developing new therapies to prevent and treat infertility and improve quality of life of patients and their partners [2]. Various factors can cause female infertility, including several reproductive system disorders that impair the function of reproductive organs. The ovary is an intricate, highly regulated reproductive organ, that has both gametogenic and secretory functions. Through folliculogenesis, the ovary produces mature oocytes enclosed within fluid-filled follicles that produce and respond to various hormones and growth factors. Ovarian function is dependent on an array of coordinated autocrine, endocrine, and paracrine signaling pathways. Ovarian dysfunction can result from a number of reproductive system disorders, which lead to not only infertility, but also systemic health complications [3-5].

Several laboratory studies and clinical trials are investigating stem cells as a strategy for treating ovarian dysfunction and endometrial disorders that lead to infertility. In particular, several studies have focused on mesenchymal stem cells (MSCs) as an experimental approach to restoring ovarian function and treating infertility [6-9]. There are various sources of MSCs, such as bone marrow, fat tissue, amniotic fluid, umbilical cord tissue, placental tissue, menstrual blood, salivary gland, 
Wharton jelly, dental pulp and pluripotent stem cells $[10,11]$. The therapeutic potential of MSCs is due to its differentiation into multiple cell lineages and regulation of immune responses via immunomodulation [12] MSCs can differentiate into epithelial, stromal, and endothelial cells, and have been shown to restore endometrial function and improve pregnancy outcomes [13]. Several studies have reported that MSC transplantation improves ovarian function and ovarian reserve, and this action may be mediated by paracrine signaling pathways [14]. However, previous studies have also suggested that the number of differentiated MSCs is not sufficient to account for the observed improvement in fertility, and controversy remains regarding the differentiation of MSCs into oocytes after migrating to target tissue [5]. Here, we first review the various reproductive system disorders that cause infertility in women, then review the progress that has been made and the remaining challenges we face in applying MSCs to the treatment of these disorders. This information may help guide future laboratory experiments and clinical trials of MSCs as a promising therapy for restoring fertility, which affects a significant number of women all over the world.

\section{Female Reproductive System Disorders}

Disorders of the female reproductive system are associated with abnormalities in one or more the reproductive organs: ovaries, uterus, fallopian tubes, and cervix. These disorders can cause severe symptoms, including pain, frequent urination, altered menstruation, and are linked to negative reproductive outcomes, such as miscarriage and infertility. In this section, we briefly review five of the most common disorders that lead to infertility in women: premature ovarian failure (POF), polycystic ovary syndrome (PCOS), endometriosis, Asherman syndrome, and preeclampsia [3-5] (Figure 1).

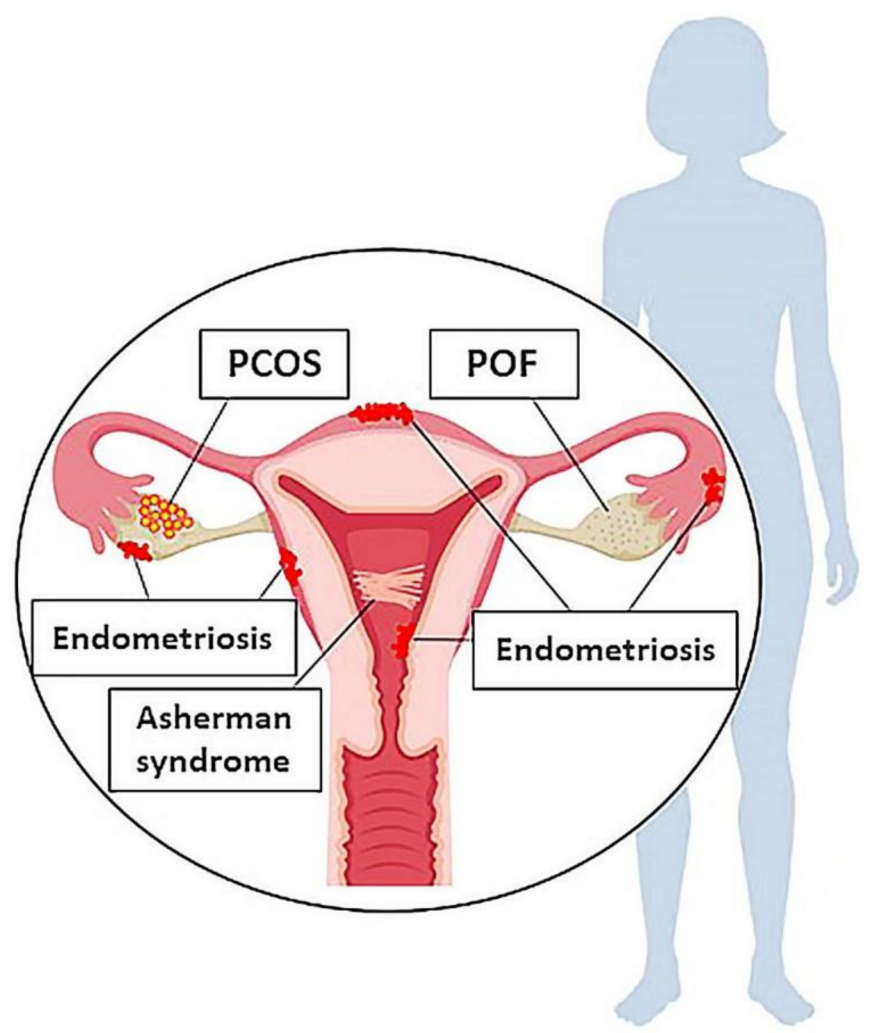

Figure 1. A schematic representation of the most important diseases of female reproductive system (including POF, PCOS, endometriosis, and Asherman syndrome). POF, Premature Ovarian Failure; PCOS, Polycystic Ovary Syndrome. 


\section{1. $P O F$}

POF, also called primary ovarian insufficiency, presents with amenorrhea, hypergonadotropism, and estrogen deficiency, followed by infertility, prior to the age of 40 years. It is estimated that POF affects $1 \%$ of all women worldwide [15]; however, its incidence has increased in recent years [16]. POF is a heterogeneous disorder due to its multicausal pathogenesis, involving genetic, infectious, enzymatic, and iatrogenic factors. Some POF patients have idiopathic POF, with no identified etiology [17]. Available therapies for POF have low efficacy and may cause significant side effects, and there is a clear need for more comprehensive therapy to restore ovarian function in those with POF [16].

\subsection{PCOS}

PCOS is a common endocrine condition characterized by excess ovarian function and chronic anovulation, which can affect female fertility. PCOS is usually characterized by high androgen levels, altered menstruation, and small cysts on one or both ovaries. It is estimated that at least $7 \%$ of adult women struggle with this disorder. Remarkably, $5 \%$ to $10 \%$ of women $18-44$ years of age have PCOS, making it the most common endocrine disorder among women of reproductive age. Recent investigations have shown that PCOS is linked to low-grade chronic inflammation $[18,19]$. Therefore, approaches to modulate the immune system and inflammatory pathways may be useful in treating PCOS.

\subsection{Endometriosis}

The endometrium is a thick, blood vessel-rich layer of tissue that develops on the surface of the uterus during the menstrual or estrous cycle. It is the deepest lining of the uterus, acts to preserve the uterine cavity patency, and is essential for early embryo implantation and growth. It is sloughed off and regenerated in every reproductive cycle. It contains a basal and a functional zone that are regulated by estrogen and progesterone [20,21]. Endometriosis is a chronic gynecological disorder characterized by the presence of endometrium tissue growing outside of the uterus. Ectopic endometrial tissue can be found on the ovaries, the uterosacral and broad ligaments, and the pelvic peritoneum. The typical outcomes of this disorder are pelvic pain and infertility. The prevalence of endometriosis is between $6 \%$ to $10 \%$, and it is a multifactorial disorder [22,23], with a combination of genetic, environmental, and immune factors determining the risk of endometriosis. Several studies have suggested that the development of endometriosis is possibly a polygenetic process driven by parallel modifications in many biological pathways that allow endometrial cells to attach to the pelvic peritoneum, proliferate, and invade the underlying tissue [22,24].

\subsection{Asherman syndrome}

Asherman syndrome is an acquired condition identified by intrauterine adhesions, hypomenorrhea, and infertility. Scar tissue or adhesions form inside the uterus and impair implantation of the blastocyst, leading to recurrent miscarriage or infertility [25]. Asherman syndrome is often undetectable by routine tests or examinations. It is estimated that more than $90 \%$ of women with Asherman syndrome develop it after pregnancy-related curettage. Indeed, its prevalence is estimated to be up to $13 \%$ in women who underwent an abortion and 30\% in women who underwent dilation and curettage after a late spontaneous abortion. Although this disease has been extensively studied, no effective treatments are available $[25,26]$.

\subsection{Preeclampsia}

Preeclampsia is a complication of pregnancy that is increasing in prevalence around the world. It is identified by high blood pressure, proteinuria, and edema. Preeclampsia frequently develops after 20 weeks of pregnancy in females who had normal blood pressure. Its incidence is $3-7 \%$ among nulliparous women and 1-3\% among multiparous women [27]. Preeclampsia is one of the main causes 
of preterm birth and fetal mortality and morbidity, and in low-income and middle-income countries, it is linked to $10-15 \%$ of fetal deaths. While preeclampsia has a complex pathophysiology, most clinical studies propose that the placenta plays a central role [28,29]. There are applicable guidelines for clinicians treating preeclampsia to reduce maternal and neonatal morbidity [29].

\section{Mesenchymal Stem cells (MSCs)}

MSCs have received increasing attention for their potential therapeutic utility in various female reproductive system disorders. The Mesenchymal and Tissue Stem Cell Committee of the International Society for Cellular Therapy introduced specific criteria for MSCs used in research and for clinical applications [30]. First, MSCs should be plastic-adherent when preserved in standard cell culture media. Second, MSCs should have a specific gene expression pattern with expression of the surface molecules CD73, CD90, and CD105, and without the expression of CD11b, CD14, CD19, CD34, CD45, and CD79a. Finally, MSCs should have the ability to differentiate into various cell types, including adipocytes, osteoblasts, and chondroblasts, in cell culture conditions [30-32]. The various MSCs are categorized according to their source.

Several studies have examined the application of MSCs for treating fertility, in particular, by restoring ovarian function in the context of various gynecologic disorders [6-9]. MSCs have been shown to spontaneously translocate to the injured ovary and attach and proliferate in response to various growth factors and hormones. These studies have reported that MSCs improve ovarian function and help ovarian functional recovery, but it remains unclear whether this effect is achieved through differentiation of MSCs into oocytes or supporting follicular or stromal cells after migration to the ovary [5].

Many studies indicated that the reproductive treatment effect of BMSC is linked to their secretome, which is rich in bioactive factors that support in ovarian function [33]. These molecules may include insulin-like growth factor (IGF), vascular endothelial growth factor (VEGF), and other growth factors that induce cell growth, differentiation, and immunoregulation to restore ovarian function [34]. Some data further suggest that the paracrine activity of MSCs has a more significant effect on ovary function than its stimulatory effects on cell growth and differentiation $[5,34]$. Growing evidence in animal studies and preliminary clinical trials has revealed that MSCs also have immunomodulatory effects through interaction with immune cells. Importantly, MSC paracrine function is tightly regulated by RAP1/NFkb signaling pathway [35]. NFkb signaling pathway is highly active in reproductive system disorders accompanied with inflammation. These effects seem to be related to pathways that induce regeneration and angiogenesis, which may also improve ovarian function. This potential mechanism of MSCs activity is of particular importance, since these pathways can regulate immune responses and inflammation, improve injured tissues, and stimulate progenitor cells to differentiate into specific tissue cells $[5,36]$.

Additionally, miRNAs and exosome transfer show another novel mechanism by which MSCs exert functions through transfer of mitochondria, a key player involved in many biological processes in health and disease, including in POF. Some pro-inflammatory cytokines, i.e. IL- 6 and TNF- $\alpha$, can induce MSC skeletal re-arrangement and form tunneling nanotubes (TNT) through which mitochondria mobility occurs from MSC to neighbor cells, such as airway epithelia cells, cardiomyocytes, and retinal ganglion cells. Inflammation-driven mitochondrial transfer of MSC to reproductive system cells including oocytes were also reported recently [37]. The therapeutic effects of MSC and direction of mitochondrial transfer highly depend on a niche where MSC is located. It appears that a pro-inflammatory environment can enhance MSC mitochondrial transfer into T cells, in turn, can educate immune cells to control the inflammatory response [38]. Here, we review studies of the biology and clinical utility of MSCs from several different sources to treat female reproductive system disorders. 


\subsection{Bone Marrow Stromal Cells (BMSCs)}

BMSCs comprise a heterogeneous collection of cells that support hematopoietic cells. This class of stem cells was first described by Owen and Friedenstein, who isolated them from nucleated bone marrow cells in $1988[39,40]$. BMSCs are an important source of multipotent stem cells and serve as a standard for comparison of MSCs from different sources [10].

Many studies have examined the functional nature and the differentiation capacity of BMSCs. These cells can differentiate into chondroblasts, osteoblasts, and adipocytes. Findings have shown that these cells account for only a limited number of nucleated bone marrow cells, due to their long replication cycle [10]. Interestingly, BMSCs also have the ability to differentiate into endometrial [41,42], endothelial [43], and granulosa cells (GCs) [44]. Under specific circumstances, these cells can also form new bone after bone marrow transplant. The finding that these cells can be manipulated in experimental investigations and consequently form bone in clinical applications offers an important model system for testing therapeutic strategies aimed at improving reproductive dysfunction [45].

To address the protective effects of BMSCs in improving ovarian function, it should be first noted that chemotherapy, despite its beneficial effects in cancer therapy, may lead to ovarian dysfunction and infertility. Using this model, findings have shown that BMSCs improve ovarian function and reduce ovarian failure [46-49]. Abd-Allah et al., reported that BMSCs improved ovarian function in cyclophosphamide-induced POF; BMSC treatment induced VEGF expression, increased estradiol levels, restored ovarian structure, and decreased expression of the apoptotic factor Caspase-3 [46]. Another investigation showed that BMSC treatment increased fertility and reduced ovarian dysfunction in mice after chemotherapy [49]. These remarkable effects of BMSCs may be due to angiogenic and growth factors secreted from these cells [15].

Other evaluations have reported that BMSCs can migrate to the uterus and induce the restoration and regeneration of damaged endometrium in human and animal models [41,50-52]. Indeed, Singh et al., showed the therapeutic effects of BMSC in the restoration of menstruation in a model of Asherman syndrome [53]. Other studies revealed that CD133+BMSCs can increase the proliferation rate of endometrial tissue by engrafting around blood vessels of the target cells, and producing IGF1, thrombospondin 1 , and other growth factors $[54,55]$. Moreover, several findings demonstrated that BMSC replacement was capable of improving endometrium dysfunction and infertility in patients with Asherman syndrome, by increasing endometrial receptivity, inducing angiogenesis and suppressing fibrosis [55-57].

Other lines of investigation have focused on the molecular and cellular mechanisms of action driving the observed effects of BMSCs in various disease models. A recent study showed that microRNAs (miRNAs) play a critical role in regulating stem cell differentiation and regeneration by inhibiting target mRNA translation [58]. These small non-coding RNAs may play a similar role in regulating the physiological and pathological mechanisms of stem cells and outcomes related to the ovarian function (Figure 2) [15]. Fu et al., found that overexpression of miR-21 in BMSCs is linked to follicular growth and apoptosis of GCs in female rats with cyclophosphamide-induced POF [48]. GCs are somatic steroidogenic cells that surround oocytes and are essential for their growth and development. GCs also support oocytes by producing nutrients and growth factors. GC death results in the abnormal development of oocytes [59]. The effect of miR-21 overexpression in BMSCs may be mediated by a reduction in the expression of programmed cell death protein 4 (PDCD4) and phosphatase and tensin homolog (PTEN). Moreover, miR-21 overexpression was associated with a higher level of estradiol and a lower level of follicle-stimulating hormone (FSH) [48]. Exosomes are a subset of membrane-bound extracellular vesicles that can be secreted by stem cells. They enclose various cellular compounds, including, proteins, lipids, and non-coding RNAs such as miRNAs. Exosomes are important vehicles for intercellular communication, and as such, are critical for many physiological functions. Recent studies indicated that exosomal miRNAs can regulate intercellular signal transduction and control molecular activities in different diseases [60-63]. Two studies have demonstrated a role of miRNAs carried by BMSCs-derived exosomes in promoting the recovery 
of ovarian function in a POF animal model [61,62]. Sun et al., reported that miR-644-5p carried by BMSCs-derived exosomes controls p53 signaling, thereby suppressing the death of GCs [61]. A more recent research described that BMSC-derived exosomal miR-144-5p is capable of restoring ovarian function by regulating PTEN after chemotherapy-induced POF in rats [62]. Together, these findings suggest that miRNA-regulated gene expression underlies BMSC-based therapy outcomes.

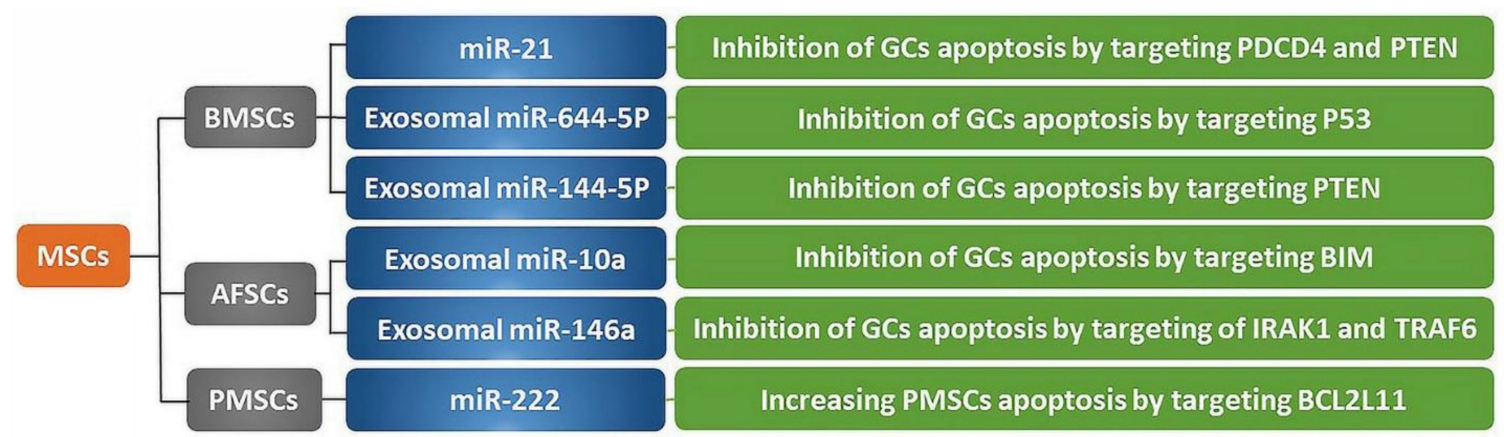

Figure 2. The association between miRNAs and different MSCs with respect to their effects on the female reproductive system. MSCs, Mesenchymal Stem Cells; BMSCs, Bone Marrow Stromal Cells; AFSCs, Amniotic Fluid Stem Cells; PMSCs, Placenta Mesenchymal Stem Cells; miR, miRNAs, microRNA; GCs, Granulosa Cells; PDCD4, Programmed Cell Death Protein 4; PTEN, Phosphatase and Tensin Homolog; BIM, Bcl-2-Like Protein 11; IRAK1, Interleukin-1 Receptor-Associated Kinase 1; TRAF6, TNF Receptor-Associated Factor 6; BCL2L11, B-Cell Lymphoma 2 Like 11.

\subsection{Adipose-Derived Stem Cells (ADSCs)}

ADSCs are a newer source of MSCs, that have been applied successfully to tissue regeneration [64-66]. They also have some notable advantages over MSCs derived from other sources, such as BMSCs. For instance, they can be easily isolated by minimally invasive methods and have immunosuppressive functions. ADSCs have the same differentiation capacity as other MSCs, producing adipocytes, osteoblasts, and chondroblasts, as well as neural cells, cardiomyocytes, myocytes, vascular endothelial cells, and hepatocytes. Hence, these cells have the potential for broad applications in clinical settings [67-69].

Previous data have demonstrated that ADSC-based therapy upregulates VEGF expression, promotes new blood vessel growth, and improves ovarian graft quality in rats [70]. Moreover, ADSCs improved ovarian function in mice after chemotherapy, increasing the number of new blood vessels and ovarian follicles [71,72]. Adding a collagen scaffold increased the short-term preservation of ADSCs in the ovaries of female rats with POF compared to ADSC therapy alone [73]. In addition, ADSCs were found to increase the number of follicles, improve ovulation, and reduce GCs death in cyclophosphamide-induced POF [15]. Importantly, another study isolated allogeneic ADSCs from women with endometriosis to investigate their effects on endometriosis-derived cells in vitro. However, they concluded that allogeneic ADSCs should not be used as a therapeutic strategy for patients with endometriosis, since they may induce the growth of ectopic endometrial tissue and support the development of endometriosis [74]. Interestingly, using ADSCs along with estrogen increased endometrial regeneration in a female rat model of Asherman syndrome [75].

These findings suggest that ADSCs are one of the most important therapeutic cells for recovery of ovarian function, though technical challenges in replacement therapy still need to be addressed.

\subsection{Menstrual Blood-Derived Mesenchymal Stem Cells (MenSCs)}

MenSCs are a new source of MSCs that have attracted significant attention since their discovery in 2007. MenSCs are collected from menstrual blood and show some exclusive characteristics of better-known stem cells and offer an alternative and plentiful source of cells for clinical applications in tissue regeneration. MenSCs are easy to harvest using noninvasive techniques and have a high 
proliferation rate. There have been no reports of autoimmune rejection responses to MenSCs [76,77]. Several investigations have shown beneficial effects of MenSCs in different diseases, including neurodegenerative disorders [77-79]. Remarkably, some studies have reported a protective role of MenSCs against GCs death in the ovarian interstitium of an animal model of POF. In these studies, MenSCs restored ovarian function [80,81]. It was suggested that this effect is likely mediated by a decrease in the expression of growth arrest and DNA damage inducible beta (GADD45B), a stress sensor involved in cell cycle control, and by an increase in the expression of cell division control 2 (CDC2) and cyclin B1 as cell cycle inducers [82-85]. Moreover, another study showed that MenSCs treatment led to higher levels of fibroblast growth factor 2 (FGF2), with beneficial effects on ovarian structure and function [86].

The endometrium comprises a subset of cells presenting MenSCs properties. Interestingly, MenSCs collected from ectopic endometriotic lesions appear to promote the pathogenesis of endometriosis [87, 88]. Despite this, various studies have reported on the use of MenSCs to improve endometrial growth and proliferation in the injured endometrium and reducing inflammation and fibrosis through Wnt family member 5 a (Wnt5a) and growth differentiation factor 5 (Gdf5) growth factors and the Hippo signaling pathway [89]. For instance, in 2018, Zheng et al., were the first to demonstrate the ability of MenSCs to differentiate into endometrial cells in the laboratory and rebuild endometrial tissue in animal models in response to estrogen and progesterone [90]. Moreover, MenSCs treatment, along with hormonal stimulation, was shown to improve endometrium structure and fertility potential in women with Asherman syndrome [91]. Domnina et al., reported that MenSCs treatment increases fertility through induction of angiogenic and anti-inflammatory factors in a rat model of Asherman syndrome [92]. Other work has found that MenSCs produce functional spheroids, which appear to be essential for their observed therapeutic effects [93].

\subsection{Umbilical Cord Mesenchymal Stem Cells (UC-MSCs)}

UC-MSCs are a rich source of MSCs that express stem cell-specific markers and can be differentiated into several mesodermal cell types for tissue repair and regulation of the immune response. US-MSCs have some notable features, including fast self-renewal, lower oncogenicity, poor immunogenic properties, and ability to collect them in a painless and non-invasive fashion [94]. Their poor immunogenic properties are due to a lower expression of major histocompatibility complex (MHC) class I and class II proteins needed for adaptive immunity. Considering these features, UC-MSCs have emerged as a superior source of stem cells for transplantation compared to other sources of MSCs. Several methods have been developed for isolating these cells from Wharton's jelly, arteries, or veins [15,94-96].

Some groups have reported that UC-MSCs can activate primordial follicles, increase ovarian function, and decrease ovarian cell death in both animal and human models of POF, particularly in the presence of collagen [97-100]. After the transplantation of CM-Dil-labeled UC-MSCs into the ovaries of mice with cyclophosphamide-induced POF, the cells were unequally distributed within the ovary, with a greater number of cells located in the medulla rather than in the cortex and germinal epithelium [101].

Several factors and pathways may underlie the protective effects of UC-MSCs. For instance, some studies suggest that UC-MSCs likely decrease GCs apoptosis by affecting the Mitogen-Activated Protein Kinase (MAPK) signaling pathway, G-protein coupled receptor (GPCR) signaling pathway, and insulin signaling pathway [15]. In 2016, Elfayomy et al., showed that UC-MSCs reduced ovarian cell death by regulating critical molecules involved in inhibiting Caspase-3-induced apoptosis [102]. Other research found that UC-MSCs on a collagen scaffold activated primordial follicles by phosphorylation of the transcription factors Forkhead box protein O1 (FOXO1) and FOXO3a $[103,104]$. Furthermore, UC-MSCs have been reported to induce angiogenic growth factors, including VEGF, hepatocyte growth factor (HGF), placental growth factor (PGF), and transforming growth factor-beta 1 (TGF- $\beta 1$ ) $[15,105]$.

New evidence suggests that the potential utility of UC-MSC transplantation improves pathological alterations in PCOS. Researchers found that UC-MSC transplantation restored ovarian function 
in dehydroepiandrosterone (DHEA)-induced PCOS in mice. This effect was mediated by the downregulation of inflammatory cytokine expression, including interleukin 1 beta (IL-1 $\beta$ ), tumor necrosis factor alpha (TNF- $\alpha$ ), and interferon gamma (IFN- $\gamma$ ), as well as fibrosis-related genes such as connective tissue growth factor (CTGF) [36]. While these studies suggest that UC-MSC transplantation may be helpful for controlling disorders related to the ovaries, more studies are needed to develop a valid US-MSC-based therapeutic approach.

Several studies have investigated the effects of UC-MSCs in endometrial regeneration. UC-MSCs were found to restore injured endometrial tissue in cesarean delivery scars [106,107], and remarkably, the differentiation of UC-MSCs into endometrial cells was observed in a recent study [108]. It has been demonstrated that UC-MSCs improved endometrial injury and infertility by inhibiting inflammation and excessive fibrosis, and increasing cell proliferation and vascular marker expression [109]. Recent findings showed that UC-MSCs on a collagen scaffold restored the endometrium by inducing the expression of matrix metalloproteinase 9 (MMP9) in rats [110,111]. Furthermore, UC-MSCs on a collagen scaffold were useful in treating patients with recurrent uterine adhesions through the induction of von Willebrand factor (VWF), Ki67, vimentin, and estrogen receptor alpha (ER $\alpha$ ) gene expression, thereby increasing cell proliferation and differentiation [112].

Remarkably, several studies have demonstrated positive effects of UC-MSC transplantation on preeclampsia. In a lipopolysaccharide (LPS)-induced preeclampsia rat model, UC-MSC transplantation improved preeclampsia symptoms and reduced the levels of inflammatory cytokines such as TNF- $\alpha$ and IL-6 [113]. This effect of UC-MSCs was also observed in an endotoxin-induced preeclampsia rat model, with a decrease in TNF- $\alpha$ and IL-1 $\beta$ levels [114]. Moreover, UC-MSC improved angiotensin receptor agonistic autoantibody (AT1-AA)-induced pregnancy hypertension and reduced the serum levels of TNF- $\alpha$, providing further evidence that UC-MSCs may be a possible therapy for preeclampsia [115]. In another study, trophoblast cells were treated with UC-MSC to investigate the effects on migration and proliferation. The investigators observed a protective effect of UC-MSC on trophoblast cellular functions, opening a new avenue for treating placenta-related disorders like preeclampsia [116]. Interestingly, exosomes derived from UC-MSC improved the morphology and angiogenesis of the placenta in a dose-dependent manner in a rat model of preeclampsia [117]. Taken together, UC-MSCs may be beneficial for preeclampsia therapy, and further studies are warranted.

\subsection{Amniotic Fluid Stem Cells (AFSCs)}

Amniotic fluid supports fetal growth and development by providing essential nutrients during embryogenesis and gestation [46]. Amniotic fluid is also a novel source of stem cells with potentially broad applications. AFSCs are not only appropriate for use as therapy, but may have clinical value for the diagnosis of ovarian dysfunction. These cells lack the ethical limitations of embryonic stem cells and show immunomodulatory characteristics. AFSCs can be collected easily and be differentiated into several cell types, including bone, muscle, and adipose cells for use in regenerative treatments [118]. The capacity of AFSCs to repair bone, cartilage, and muscle has been investigated in several animal models [119-122].

Previous data have indicated that AFSCs may modulate ovarian function by regulating paracrine signaling pathways, such as TGF- $\alpha$, TGF- $\beta$, FGF1, VEGF, bone morphogenetic protein 4 (BMP-4), and epidermal growth factor (EGF) pathways [15]. Thus, although AFSCs do not differentiate into GCs in vivo, AFSCs have been shown to improve ovarian function in a mouse model of POF by suppressing follicular atresia and preserving healthy follicles [123]. Moreover, Liu et al., reported that a subpopulation of CD4C/CD105+ AFSCs improved the regeneration of ovarian cells after chemotherapy-induced POF in mice [124].

Considering the role of exosomal miRNAs in the restorative effects of MSCs in the ovaries, the potential role of exosomal miR-10a and miR-146a derived from AFSCs has been investigated. In this report, two AFSC exosomal miRNAs increased the survival of GCs and improved follicular atresia by targeting Bcl-2-like protein 11 (BIM), interleukin-1 receptor-associated kinase 1 (IRAK1), 
and TNF receptor-associated factor 6 (TRAF6), after chemotherapy-induced POF. Moreover, the downregulation of miR-10a and miR-146a suppressed their protective effects on the survival of injured GCs. Importantly, the administration of miR-10a and miR-146a restored the effect on GCs survival, with miR-10a showing a greater effect. These data suggest that these and possibly other miRNAs may offer a new therapeutic strategy for modulating and treating ovarian dysfunction [125]. However, there are some limitations to their clinical utility. The systemic administration of miRNAs in high doses may have some dangerous side effects, based on their known roles in various physiological and pathophysiological mechanisms. To address this challenge, investigators found that the local injection of miRNAs into areas of tissue damage could elicit benefits while reducing side effects, as these small molecules have a short half-life $[125,126]$.

\subsection{Amnion-Derived Mesenchymal Stem Cells (AD-MSCS)}

AD-MSCs are another potential cell source for regenerative medicine and transplantation. They can be easily collected from human amnion using noninvasive methods. Two recent studies demonstrated their beneficial effects on ovarian function in a chemotherapy induced POF rat model $[34,127]$. They reported that AD-MSCs can protect against chemotherapy-induced POF by decreasing GCs apoptosis and increasing cell proliferation and angiogenesis through paracrine signaling pathways in the ovarian microenvironment. Furthermore, AD-MSCs inhibited chemotherapy-induced inflammation by reducing inflammatory cytokines, such as IL- $1 \beta$, IL- 6 , and TNF- $\alpha$ in the ovaries. Indeed, in a study using low-intensity pulsed ultrasound (LIPUS)-pretreated AD-MSCs, the expression of several growth factors, including IGF1, FGF2, and VEGF, reduced the expression of IL-1 $\beta$, IL-6, and TNF- $\alpha$ in the ovaries of POF rats. Interestingly, LIPUS pretreatment with AD-MSC transplantation was more effective in decreasing chemotherapy-induced inflammation and apoptosis in the ovarian tissue of POF rats [128]. However, Hwang et al., examined the levels of monocyte chemotactic protein-1 (MCP-1), one of the key chemokines in normal and preeclamptic pregnancies but observed no significant difference in its expression in AD-MSCs [129]. Collectively, AD-MSC transplantation appears to reduce ovarian injury and may be a novel therapy for disorders such as POF to improve reproductive health.

\subsection{Placenta Mesenchymal Stem Cells (PMSCs)}

PMSCs are a new class of stem cells for transplantation, with the potential to restore ovarian function in POF. They can be isolated easily and have poor immunogenic properties. They also have some remarkable advantages over other MSCs, due to their high differentiation and proliferation potential, making them an attractive cell source for transplantation and regenerative medicine [15]. This new class of stem cells was shown to improve ovarian function in POF mice via the regulation of cytokines. Moreover, PMSCs were able to reduce the levels of estradiol, $\mathrm{FSH}$, and luteinizing hormone (LH) and induce the expression of FSH receptor (FSHR) and anti-Müllerian hormone (AMH) in POF mice. FSHR mediates FSH signaling during folliculogenesis. AMH also plays a key role in the regulation of folliculogenesis and is an indicator of the ovarian reserve. The same study also revealed that the PI3K/Akt signaling pathway contributes to the effects of PMSC transplantation on ovarian function [130-132]. In addition, Li et al., reported that PMSC transplantation decreased GCs apoptosis through the inhibition of the endoplasmic reticulum (ER) stress inositol-requiring enzyme 1 (IRE1) signaling pathway, thereby improving ovarian structure and function in POF mice [133]. Furthermore, PMSC transplantation was shown to improve ovarian function in ovariectomized rats by inducing the production of estrogen and the expression of folliculogenesis-related genes [134].

Stem cell transplantation has great potential for the treatment of preeclampsia as a pregnancy-specific hypertensive disorder. PMSCs produce a wide array of inflammatory cytokines and growth factors that play key roles in modulating the signaling pathways underlying preeclampsia [129,135-138]. Moreover, previous findings have demonstrated that miRNAs such as miR-222 influence PMSCs differentiation and activity in preeclampsia, by targeting B-cell lymphoma 2 like 11 (BCL2L11) [139]. It was also reported that PMSCs interfere with the regulators of the G1/S 
phase cell cycle checkpoint in patients with preeclampsia [140]. Therefore, PMSCs may provide a future therapeutic tool for placenta-related diseases like preeclampsia. Nevertheless, more studies are needed to decipher their exact role in the etiopathology of the disorder.

\subsection{Pluripotent Stem Cell-derived MSCs (PSC-MSCs)}

MSCs can also be derived from pluripotent stem cells (PSCs), which have capabilities of rejuvenation of tissues [11]. In 2010, Lian et al., showed that PSC-MSCs can be differentiated into osteoblasts, adipocytes, chondrocytes and promote angiogenesis [141]. The literature also reported that MSCs derived from PSCs have better survival rates after engraftment in disease condition. It is due to higher telomerase activity of PSC-MSCs with less senescence property compared to the BM-MSCs. MSCs derived from pluripotent stem cells have higher proliferative potential and showed stronger immunomodulation properties than bone-marrow-derived MSCs [142]. PSC-MSCs are devoid of teratoma formation inherent to its parental cell population, even with their higher proliferation than BM-MSCs [143]. Recent studies using GMP-grade MSCs derived from iPSCs have been used in refractory graft-versus-host-disease (GVHD) in clinical trials [144], though many female reproductive system disorders are related to aberrant inflammation and abnormal immune states. Therefore, PSC-MSCs may provide another putative cellular source for infertility disorders, due to strong immunomodulatory properties [142].

From this study we can summarize the effect of different MSCs in female reproductive diseases (Table 1).

Table 1. Effects of different MSCs on female reproductive diseases.

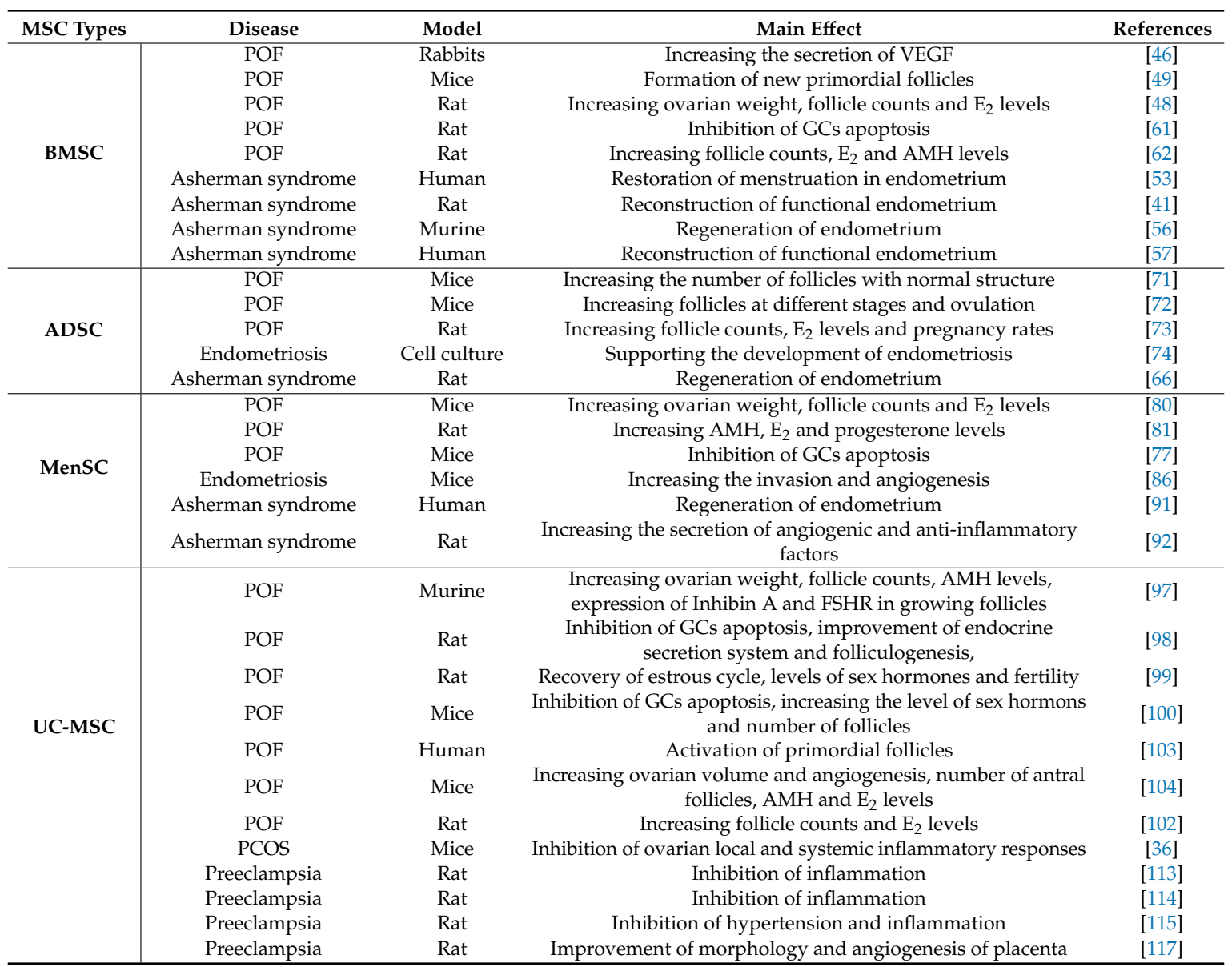


Table 1. Cont.

\begin{tabular}{|c|c|c|c|c|}
\hline MSC Types & Disease & Model & Main Effect & References \\
\hline \multirow{3}{*}{ AFSC } & POF & Mice & $\begin{array}{l}\text { Inhibition of follicular atresia and preserving the healthy } \\
\text { follicles }\end{array}$ & [123] \\
\hline & POF & Mice & Regeneration of ovarian cells & [124] \\
\hline & POF & Mice & Inhibition of GCs apoptosis and follicular atresia & [125] \\
\hline \multirow{3}{*}{ AD-MSC } & POF & Rat & $\begin{array}{l}\text { Inhibition of GCs apoptosis, increasing ovarian angiogenesis } \\
\text { and follicular development }\end{array}$ & [34] \\
\hline & POF & Rat & $\begin{array}{l}\text { Inhibition of GCs apoptosis, increasing follicular numbers and } \\
\qquad \mathrm{AMH} \text { levels }\end{array}$ & [127] \\
\hline & POF & Rat & Inhibition of inflammation & [128] \\
\hline \multirow{5}{*}{ PMSC } & POF & Mice & Inhibition of GCs apoptosis, increasing $\mathrm{E}_{2}$ levels & [130] \\
\hline & POF & Mice & Inhibition of GCs apoptosis, improvement of ovarian function & [131] \\
\hline & POF & Mice & Increasing follicular numbers, $\mathrm{E}_{2}$ and $\mathrm{AMH}$ levels & [132] \\
\hline & POF & Mice & Inhibition of GCs apoptosis & [133] \\
\hline & Preeclampsia & Human & Increasing the production of HGF & [137] \\
\hline
\end{tabular}

MSC, Mesenchymal Stem Cell; BMSC, Bone Marrow Stromal Cell; ADSC, Adipose-Derived Stem Cell; MenSC, Menstrual Blood-Derived Mesenchymal Stem Cell; UC-MSC, Umbilical Cord Mesenchymal Stem Cell; AFSC, Amniotic Fluid Stem Cell; AD-MSC, Amnion-Derived Mesenchymal Stem Cell; PMSC, Placenta Mesenchymal Stem Cell; POF, Premature Ovarian Failure; PCOS, Polycystic Ovary Syndrome; GC, Granulosa Cell; E2, Estradiol; AMH, Anti-mullerian hormone.

\section{Conclusions}

MSCs have shown great potential for treating female infertility in various animal models and clinical studies. MSCs exert their effects through the modulation of various molecular and biological pathways. miRNAs and exosomal miRNAs in particular appear to play an important role in mediating MSCs effects and are thus novel therapeutic targets for further study. Studies have advanced our understanding of the mechanisms and therapeutic potential of stem cell-based therapies for gynecologic disorders that alter reproductive tissue function. These studies have also opened opportunities for the development of novel and effective MSC-based treatments, with the potential to help women with infertility or ovarian insufficiency by restoring their reproductive health and improving their quality of life. The utilization of MSC in female infertility treatment is at stages of pre-clinical research or a very early clinical trial phase. The safety and efficacy of MSC in infertility treatment require further investigation. Different disease conditions between the animal model and human, MSC quality and dosage and routes of MSC delivery must be carefully evaluated. Further studies of MSCs function in transplantation and regenerative medicine are needed.

Author Contributions: S.E. and R.M.C. designed and wrote the manuscript. S.E., R.M.C., H.-s.P. and M.U. searched the literature. S.E., R.M.C. and E.H. edited the manuscript and A.A.-H. led the entire study as a corresponding author. All authors have read and agreed to the published version of the manuscript.

Funding: This work was supported in part by NIH (NIEHS), Grant\#: R01 ES028615 (A.A.) and the University of Chicago start up fund.

Acknowledgments: Authors are grateful to NIH and University of Chicago to provide the funds for this study.

Conflicts of Interest: The authors declare no conflict of interest.

\section{References}

1. Hull, M.; Glazener, C.M.; Kelly, N.J.; Conway, D.I.; Foster, P.A.; Hinton, R.A.; Coulson, C.; Lambert, P.A.; Watt, E.M.; Desai, K.M. Population study of causes, treatment, and outcome of infertility. Br. Med. J. (Clin. Res. Ed.) 1985, 291, 1693-1697. [CrossRef] [PubMed]

2. Sun, H.; Gong, T.T.; Jiang, Y.T.; Zhang, S.; Zhao, Y.H.; Wu, Q.J. Global, regional, and national prevalence and disability-adjusted life-years for infertility in 195 countries and territories, 1990-2017: Results from a global burden of disease study, 2017. Aging 2019, 11, 10952-10991. [CrossRef] [PubMed]

3. Jobling, P.; O'Hara, K.; Hua, S. Female reproductive tract pain: Targets, challenges, and outcomes. Front. Pharmacol. 2014, 5, 17. [CrossRef] [PubMed] 
4. Crain, D.A.; Janssen, S.J.; Edwards, T.M.; Heindel, J.; Ho, S.M.; Hunt, P.; Iguchi, T.; Juul, A.; McLachlan, J.A.; Schwartz, J.; et al. Female reproductive disorders: The roles of endocrine-disrupting compounds and developmental timing. Fertil. Steril. 2008, 90, 911-940. [CrossRef]

5. Zhao, Y.X.; Chen, S.R.; Su, P.P.; Huang, F.H.; Shi, Y.C.; Shi, Q.Y.; Lin, S. Using Mesenchymal Stem Cells to Treat Female Infertility: An Update on Female Reproductive Diseases. Stem Cells Int. 2019, 2019, 9071720. [CrossRef]

6. Naji, A.; Rouas-Freiss, N.; Durrbach, A.; Carosella, E.D.; Sensébé, L.; Deschaseaux, F. Concise review: Combining human leukocyte antigen $\mathrm{G}$ and mesenchymal stem cells for immunosuppressant biotherapy. Stem Cells (Dayt. Ohio) 2013, 31, 2296-2303. [CrossRef]

7. Squillaro, T.; Peluso, G.; Galderisi, U. Clinical Trials With Mesenchymal Stem Cells: An Update. Cell Transplant. 2016, 25, 829-848. [CrossRef]

8. Galipeau, J.; Sensébé, L. Mesenchymal Stromal Cells: Clinical Challenges and Therapeutic Opportunities. Cell Stem Cell 2018, 22, 824-833. [CrossRef]

9. Trounson, A.; McDonald, C. Stem Cell Therapies in Clinical Trials: Progress and Challenges. Cell Stem Cell 2015, 17, 11-22. [CrossRef]

10. Ullah, I.; Subbarao, R.B.; Rho, G.J. Human mesenchymal stem cells-Current trends and future prospective. Biosci. Rep. 2015, 35, e00191. [CrossRef]

11. Spitzhorn, L.; Megges, M.; Wruck, W.; Rahman, S.; Otte, J.; Degistirici, O.; Meisel, R.; Sorg, R.V.; Oreffo, R.O.C.; Adjave, J. Human iPSC-derived MSCs (iMSCs) from aged individuals acquire a rejuvenation signature. Stem Cell Res. Ther. 2019, 10, 100. [CrossRef]

12. Fan, X.L.; Zhang, Y.; Li, X.; Fu, Q.L. Mechanisms underlying the protective effects of mesenchymal stem cell-based therapy. Cell. Mol. Life Sci. 2020, 77, 2771-2794. [CrossRef] [PubMed]

13. Rungsiwiwut, R.; Virutamasen, P.; Pruksananonda, K. Mesenchymal stem cells for restoring endometrial function: An infertility perspective. Reprod Med. Biol. 2020, 00, 1-7. [CrossRef]

14. Yoon, S.Y. Mesenchymal stem cells for restoration of ovarian function. Clin. Exp. Reprod. Med. 2019, 46, 1-7. [CrossRef] [PubMed]

15. Zhang, C. The roles of different stem cells on premature ovarian failure. Curr. Stem Cell Res. Ther. 2020, 15, $473-481$.

16. Chen, L.; Guo, S.; Wei, C.; Li, H.; Wang, H.; Xu, Y. Effect of stem cell transplantation of premature ovarian failure in animal models and patients: A meta-analysis and case report. Exp. Ther. Med. 2018, 15, 4105-4118. [CrossRef] [PubMed]

17. Hoek, A.; Schoemaker, J.; Drexhage, H.A. Premature Ovarian Failure and Ovarian Autoimmunity. Endocr. Rev. 1997, 18, 107-134.

18. Rocha, A.L.; Oliveira, F.R.; Azevedo, R.C.; Silva, V.A.; Peres, T.M.; Candido, A.L.; Gomes, K.B.; Reis, F.M. Recent advances in the understanding and management of polycystic ovary syndrome. F1000Research 2019, 8. F1000 Faculty Rev-565. [CrossRef]

19. Ndefo, U.A.; Eaton, A.; Green, M.R. Polycystic ovary syndrome: A review of treatment options with a focus on pharmacological approaches. Pharm. Ther. 2013, 38, 336-355.

20. Dallenbach-Hellweg, G. The endometrium of infertility. A review. Pathol. Res. Pract. 1984, 178, 527-537. [CrossRef]

21. Maybin, J.A.; Critchley, H.O. Menstrual physiology: Implications for endometrial pathology and beyond. Hum. Reprod. Update 2015, 21, 748-761. [CrossRef] [PubMed]

22. Sasson, I.E.; Taylor, H.S. Stem cells and the pathogenesis of endometriosis. Ann. N. Y. Acad. Sci. 2008, 1127, 106-115. [CrossRef] [PubMed]

23. Ceccaroni, M.; Roviglione, G.; Rosenberg, P.; Pesci, A.; Clarizia, R.; Bruni, F.; Zardini, C.; Ruffo, G.; Placci, A.; Crippa, S. Pericardial, pleural and diaphragmatic endometriosis in association with pelvic peritoneal and bowel endometriosis: A case report and review of the literature. Wideochirurgia I Inne Tech. Maloinwazyjne = Videosurg. Other Miniinvasive Tech. 2012, 7, 122-131. [CrossRef]

24. Klemmt, P.; Starzinski-Powitz, A. Molecular and Cellular Pathogenesis of Endometriosis. Curr. Women's Health Rev. 2018, 14, 106-116. [CrossRef]

25. Dreisler, E.; Kjer, J.J. Asherman's syndrome: Current perspectives on diagnosis and management. Int. J. Women's Health 2019, 11, 191-198. [CrossRef] [PubMed]

26. March, C.M. Asherman's syndrome. Semin. Reprod. Med. 2011, 29, 83-94. [CrossRef] [PubMed] 
27. Rana, S.; Lemoine, E.; Granger, J.P.; Karumanchi, S.A. Preeclampsia: Pathophysiology, Challenges, and Perspectives. Circ. Res. 2019, 124, 1094-1112. [CrossRef] [PubMed]

28. Uzan, J.; Carbonnel, M.; Piconne, O.; Asmar, R.; Ayoubi, J.M. Pre-eclampsia: Pathophysiology, diagnosis, and management. Vasc. Health Risk Manag. 2011, 7, 467-474.

29. Phipps, E.; Prasanna, D.; Brima, W.; Jim, B. Preeclampsia: Updates in Pathogenesis, Definitions, and Guidelines. Clin. J. Am. Soc. Nephrol. 2016, 11, 1102-1113. [CrossRef]

30. Dominici, M.; Le Blanc, K.; Mueller, I.; Slaper-Cortenbach, I.; Marini, F.; Krause, D.; Deans, R.; Keating, A.; Prockop, D.j.; Horwitz, E. Minimal criteria for defining multipotent mesenchymal stromal cells. The International Society for Cellular Therapy position statement. Cytotherapy 2006, 8, 315-317. [CrossRef]

31. Krampera, M.; Galipeau, J.; Shi, Y.; Tarte, K.; Sensebe, L.; MSC Committee of the International Society for Cellular Therapy (ISCT). Immunological characterization of multipotent mesenchymal stromal cells-The International Society for Cellular Therapy (ISCT) working proposal. Cytotherapy 2013, 15, 1054-1061. [CrossRef] [PubMed]

32. Galipeau, J.; Krampera, M.; Barrett, J.; Dazzi, F.; Deans, R.J.; DeBruijn, J.; Dominici, M.; Fibbe, W.E.; Gee, A.P.; Gimble, J.M.; et al. International Society for Cellular Therapy perspective on immune functional assays for mesenchymal stromal cells as potency release criterion for advanced phase clinical trials. Cytotherapy 2016, 18, 151-159. [CrossRef] [PubMed]

33. Harrell, C.R.; Fellabaum, C.; Jovicic, N.; Djonov, V.; Arsenijevic, N.; Volarevic, V. Molecular Mechanisms Responsible for Therapeutic Potential of Mesenchymal Stem Cell-Derived Secretome. Cells 2019, 8, 467. [CrossRef]

34. Ling, L.; Feng, X.; Wei, T.; Wang, Y.; Wang, Y.; Wang, Z.; Tang, D.; Luo, Y.; Xiong, Z. Human amnion-derived mesenchymal stem cell (hAD-MSC) transplantation improves ovarian function in rats with premature ovarian insufficiency (POI) at least partly through a paracrine mechanism. Stem Cell Res. Ther. 2019, 10, 46. [CrossRef] [PubMed]

35. Zhang, Y.; Chiu, S.; Liang, X.; Gao, F.; Zhang, Z.; Liao, S.; Liang, Y.; Chai, Y.H.; Low, D.J.; Tse, H.F. Rap1-mediated nuclear factor-kappaB (NF-kB) activity regulates the paracrine capacity of mesenchymal stem cells in heart repair following infarction. Cell Death Discov. 2015, 1, 15007. [CrossRef]

36. Xie, Q.; Xiong, X.L.; Xiao, N.; He, K.; Chen, M.S.; Peng, J.; Su, X.; Mei, H.; Dai, Y.N.; Wei, D.; et al. Mesenchymal Stem Cells Alleviate DHEA-Induced Polycystic Ovary Syndrome (PCOS) by Inhibiting Inflammation in Mice. Stem Cells Int. 2019, 12. [CrossRef]

37. Wang, Z.B.; Hao, J.X.; Meng, T.G.; Guo, L.; Dong, M.Z.; Fan, L.H.; Ouyang, Y.C.; Wang, G.; Sun, Q.Y.; $\mathrm{Ou}$, X.H.; et al. Transfer of autologous mitochondria from adipose tissue-derived stem cells rescues oocyte quality and infertility in aged mice. Aging 2017, 9, 2480-2488. [CrossRef]

38. Court, A.C.; Le-Gatt, A.; Luz-Crawford, P.; Parra, E.; Aliaga-Tobar, V.; Bátiz, L.F.; Contreras, R.A.; Ortúzar, M.I.; Kurte, M.; Elizondo-Vega, R. Mitochondrial transfer from MSCs to T cells induces Treg differentiation and restricts inflammatory response. EMBO Rep. 2020, 21, e48052. [CrossRef]

39. Owen, M.; Friedenstein, A.J. Stromal stem cells: Marrow-derived osteogenic precursors. Ciba Found. Symp. 1988, 136, 42-60.

40. Altaner, C.; Altanerova, V.; Cihova, M.; Hunakova, L.; Kaiserova, K.; Klepanec, A.; Vulev, I.; Madaric, J. Characterization of mesenchymal stem cells of "no-options" patients with critical limb ischemia treated by autologous bone marrow mononuclear cells. PLoS ONE 2013, 8, e73722. [CrossRef]

41. Gao, L.; Huang, Z.; Lin, H.; Tian, Y.; Li, P.; Lin, S. Bone Marrow Mesenchymal Stem Cells (BMSCs) Restore Functional Endometrium in the Rat Model for Severe Asherman Syndrome. Reprod. Sci. (Thousand Oakscalif.) 2019, 26, 436-444. [CrossRef] [PubMed]

42. Liu, Y.; Tal, R.; Pluchino, N.; Mamillapalli, R.; Taylor, H.S. Systemic administration of bone marrow-derived cells leads to better uterine engraftment than use of uterine-derived cells or local injection. J. Cell. Mol. Med. 2018, 22, 67-76. [CrossRef] [PubMed]

43. Tepper, O.M.; Sealove, B.A.; Murayama, T.; Asahara, T. Newly emerging concepts in blood vessel growth: Recent discovery of endothelial progenitor cells and their function in tissue regeneration. J. Investig. Med. 2003, 51, 353-359. [CrossRef] [PubMed]

44. Besikcioglu, H.E.; Sarıbas, G.S.; Ozogul, C.; Tiryaki, M.; Kilic, S.; Pınarlı, F.A.; Gulbahar, O. Determination of the effects of bone marrow derived mesenchymal stem cells and ovarian stromal stem cells on follicular 
maturation in cyclophosphamide induced ovarian failure in rats. Taiwan. J. Obstet. Gynecol. 2019, 58, 53-59. [CrossRef] [PubMed]

45. Wei, X.; Yang, X.; Han, Z.P.; Qu, F.F.; Shao, L.; Shi, Y.F. Mesenchymal stem cells: A new trend for cell therapy. Acta Pharmacol. Sin. 2013, 34, 747-754. [CrossRef] [PubMed]

46. Abd-Allah, S.H.; Shalaby, S.M.; Pasha, H.F.; El-Shal, A.S.; Raafat, N.; Shabrawy, S.M.; Awad, H.A.; Amer, M.G.; Gharib, M.A.; El Gendy, E.A.; et al. Mechanistic action of mesenchymal stem cell injection in the treatment of chemically induced ovarian failure in rabbits. Cytotherapy 2013, 15, 64-75. [CrossRef] [PubMed]

47. Mohamed, S.A.; Shalaby, S.M.; Abdelaziz, M.; Brakta, S.; Hill, W.D.; Ismail, N.; Al-Hendy, A. Human Mesenchymal Stem Cells Partially Reverse Infertility in Chemotherapy-Induced Ovarian Failure. Reprod. Sci. (Thousand Oakscalif.) 2018, 25, 51-63. [CrossRef]

48. Fu, X.; He, Y.; Wang, X.; Peng, D.; Chen, X.; Li, X.; Wang, Q. Overexpression of miR-21 in stem cells improves ovarian structure and function in rats with chemotherapy-induced ovarian damage by targeting PDCD4 and PTEN to inhibit granulosa cell apoptosis. Stem Cell Res. Ther. 2017, 8, 187. [CrossRef]

49. Badawy, A.; Sobh, M.A.; Ahdy, M.; Abdelhafez, M.S. Bone marrow mesenchymal stem cell repair of cyclophosphamide-induced ovarian insufficiency in a mouse model. Int. J. Women's Health 2017, 9, 441-447. [CrossRef]

50. Taylor, H.S. Endometrial cells derived from donor stem cells in bone marrow transplant recipients. JAMA 2004, 292, 81-85. [CrossRef]

51. Nagori, C.B.; Panchal, S.Y.; Patel, H. Endometrial regeneration using autologous adult stem cells followed by conception by in vitro fertilization in a patient of severe Asherman's syndrome. J. Hum. Reprod. Sci. 2011, 4, 43-48. [PubMed]

52. Wang, J.; Ju, B.; Pan, C.; Gu, Y.; Zhang, Y.; Sun, L.; Zhang, B.; Zhang, Y. Application of Bone Marrow-Derived Mesenchymal Stem Cells in the Treatment of Intrauterine Adhesions in Rats. Cell. Physiol. Biochem. 2016, 39, 1553-1560. [CrossRef] [PubMed]

53. Singh, N.; Mohanty, S.; Seth, T.; Shankar, M.; Bhaskaran, S.; Dharmendra, S. Autologous stem cell transplantation in refractory Asherman's syndrome: A novel cell based therapy. J. Hum. Reprod. Sci. 2014, 7, 93-98. [CrossRef] [PubMed]

54. Santamaria, X.; Cabanillas, S.; Cervelló, I.; Arbona, C.; Raga, F.; Ferro, J.; Palmero, J.; Remohí, J.; Pellicer, A.; Simón, C. Autologous cell therapy with CD133+ bone marrow-derived stem cells for refractory Asherman's syndrome and endometrial atrophy: A pilot cohort study. Hum. Reprod. (Oxf. Engl. ) 2016, 31, 1087-1096. [CrossRef] [PubMed]

55. Cervelló, I.; Gil-Sanchis, C.; Santamaría, X.; Cabanillas, S.; Díaz, A.; Faus, A.; Pellicer, A.; Simón, C. Human CD133(+) bone marrow-derived stem cells promote endometrial proliferation in a murine model of Asherman syndrome. Fertil. Steril. 2015, 104, 1552-1560.e603. [CrossRef] [PubMed]

56. Alawadhi, F.; Du, H.; Cakmak, H.; Taylor, H.S. Bone Marrow-Derived Stem Cell (BMDSC) transplantation improves fertility in a murine model of Asherman's syndrome. PLoS ONE 2014, 9, e96662. [CrossRef]

57. Zhao, G.; Cao, Y.; Zhu, X.; Tang, X.; Ding, L.; Sun, H.; Li, J.; Li, X.; Dai, C.; Ru, T. Transplantation of collagen scaffold with autologous bone marrow mononuclear cells promotes functional endometrium reconstruction via downregulating $\Delta \mathrm{Np} 63$ expression in Asherman's syndrome. Sci. China. Life Sci. 2017, 60, 404-416. [CrossRef]

58. Gangaraju, V.K.; Lin, H. MicroRNAs: Key regulators of stem cells. Nat. Reviews. Mol. Cell Biol. 2009, 10, 116-125. [CrossRef]

59. Tian, C.; Liu, L.; Ye, X.; Fu, H.; Sheng, X.; Wang, L.; Wang, H.; Heng, D.; Liu, L. Functional Oocytes Derived from Granulosa Cells. Cell Rep. 2019, 29, 4256-4267. [CrossRef]

60. Aghabozorgi, A.S.; Ahangari, N.; Eftekhaari, T.E.; Torbati, P.N.; Bahiraee, A.; Ebrahimi, R.; Pasdar, A. Circulating exosomal miRNAs in cardiovascular disease pathogenesis: New emerging hopes. J. Cell. Physiol. 2019, 234, 21796-21809. [CrossRef]

61. Sun, B.; Ma, Y.; Wang, F.; Hu, L.; Sun, Y. miR-644-5p carried by bone mesenchymal stem cell-derived exosomes targets regulation of p53 to inhibit ovarian granulosa cell apoptosis. Stem Cell Res. Ther. 2019, 10, 360. [CrossRef] [PubMed]

62. Yang, M.; Lin, L.; Sha, C.; Li, T.; Zhao, D.; Wei, H.; Chen, Q.; Liu, Y.; Chen, X.; Xu, W. Bone marrow mesenchymal stem cell-derived exosomal miR-144-5p improves rat ovarian function after chemotherapy-induced ovarian failure by targeting PTEN. Lab. Investig. 2020, 100, 342-352. [CrossRef] [PubMed] 
63. Ali, M.; Esfandyari, S.; Al-Hendy, A. Evolving role of microRNAs in uterine fibroid pathogenesis: Filling the gap! Fertil. Steril. 2020, 113, 1167-1168. [CrossRef] [PubMed]

64. Lendeckel, S.; Jödicke, A.; Christophis, P.; Heidinger, K.; Wolff, J.; Fraser, J.K.; Hedrick, M.H.; Berthold, L.; Howaldt, H.P. Autologous stem cells (adipose) and fibrin glue used to treat widespread traumatic calvarial defects: Case report. J. Cranio-Maxillo-Facial Surg. 2004, 32, 370-373. [CrossRef] [PubMed]

65. Yang, J.A.; Chung, H.M.; Won, C.H.; Sung, J.H. Potential application of adipose-derived stem cells and their secretory factors to skin: Discussion from both clinical and industrial viewpoints. Expert Opin. Biol. Ther. 2010, 10, 495-503. [CrossRef]

66. Ra, J.C.; Jeong, E.C.; Kang, S.K.; Lee, S.J.; Choi, K.H. A Prospective, Nonrandomized, no Placebo-Controlled, Phase I/II Clinical Trial Assessing the Safety and Efficacy of Intramuscular Injection of Autologous Adipose Tissue-Derived Mesenchymal Stem Cells in Patients With Severe Buerger's Disease. Cell Med. 2016, 9, 87-102. [CrossRef]

67. Choudhery, M.S.; Badowski, M.; Muise, A.; Pierce, J.; Harris, D.T. Donor age negatively impacts adipose tissue-derived mesenchymal stem cell expansion and differentiation. J. Transl. Med. 2014, 12, 8. [CrossRef]

68. Lee, R.H.; Kim, B.; Choi, I.; Kim, H.; Choi, H.S.; Suh, K.; Bae, Y.C.; Jung, J.S. Characterization and expression analysis of mesenchymal stem cells from human bone marrow and adipose tissue. Cell. Physiol. Biochem. 2004, 14, 311-324. [CrossRef]

69. Gesellschaft, D. Transfusion Medicine and Hemotherapy: Offizielles Organ der Deutschen Gesellschaft für Transfusionsmedizin und Immunhämatologie; Interdisziplinäre Zeitschrift für Infusions-und Hämotherapie, Immunhämatologie und Klinische Hämostaseologie; Karger: Berlin, Germany, 2003.

70. Damous, L.L.; Nakamuta, J.S.; Carvalho, A.E.; Carvalho, K.C.; Soares, J.M., Jr.; Simões, M.; Krieger, J.E.; Baracat, E.C. Does adipose tissue-derived stem cell therapy improve graft quality in freshly grafted ovaries. Reprod. Biol. Endocrinol. 2015, 13, 108. [CrossRef]

71. Terraciano, P.; Garcez, T.; Ayres, L.; Durli, I.; Baggio, M.; Kuhl, C.P.; Laurino, C.; Passos, E.; Paz, A.H.; Cirne-Lima, E. Cell therapy for chemically induced ovarian failure in mice. Stem Cells Int. 2014, 720753. [CrossRef]

72. Sun, M.; Wang, S.; Li, Y.; Yu, L.; Gu, F.; Wang, C.; Yao, Y. Adipose-derived stem cells improved mouse ovary function after chemotherapy-induced ovary failure. Stem Cell Res. Ther. 2013, 4, 80. [CrossRef] [PubMed]

73. Su, J.; Ding, L.; Cheng, J.; Yang, J.; Li, X.; Yan, G.; Sun, H.; Dai, J.; Hu, Y. Transplantation of adipose-derived stem cells combined with collagen scaffolds restores ovarian function in a rat model of premature ovarian insufficiency. Hum. Reprod. (Oxf. Engl. ) 2016, 31, 1075-1086. [CrossRef] [PubMed]

74. Abomaray, F.; Gidlöf, S.; Bezubik, B.; Engman, M.; Götherström, C. Mesenchymal Stromal Cells Support Endometriotic Stromal Cells In Vitro. Stem Cells Int. 2018, 7318513. [CrossRef] [PubMed]

75. Kilic, S.; Yuksel, B.; Pinarli, F.; Albayrak, A.; Boztok, B.; Delibasi, T. Effect of stem cell application on Asherman syndrome, an experimental rat model. J. Assist. Reprod. Genet. 2014, 31, 975-982. [CrossRef]

76. Meng, X.; Ichim, T.E.; Zhong, J.; Rogers, A.; Yin, Z.; Jackson, J.; Wang, H.; Ge, W.; Bogin, V.; Chan, K.W.; et al. Endometrial regenerative cells: A novel stem cell population. J. Transl. Med. 2007, 5, 57. [CrossRef]

77. Zhong, Z.; Patel, A.N.; Ichim, T.E.; Riordan, N.H.; Wang, H.; Min, W.P.; Woods, E.J.; Reid, M.; Mansilla, E.; Marin, G.H. Feasibility investigation of allogeneic endometrial regenerative cells. J. Transl. Med. 2009, 7, 15. [CrossRef]

78. Wolff, E.F.; Mutlu, L.; Massasa, E.E.; Elsworth, J.D.; Eugene Redmond, D., Jr.; Taylor, H.S. Endometrial stem cell transplantation in MPTP- exposed primates: An alternative cell source for treatment of Parkinson's disease. J. Cell. Mol. Med. 2015, 19, 249-256. [CrossRef]

79. Wolff, E.F.; Gao, X.B.; Yao, K.V.; Andrews, Z.B.; Du, H.; Elsworth, J.D.; Taylor, H.S. Endometrial stem cell transplantation restores dopamine production in a Parkinson's disease model. J. Cell. Mol. Med. 2011, 15, 747-755. [CrossRef]

80. Liu, T.; Huang, Y.; Zhang, J.; Qin, W.; Chi, H.; Chen, J.; Yu, Z.; Chen, C. Transplantation of human menstrual blood stem cells to treat premature ovarian failure in mouse model. Stem Cells Dev. 2014, 23, 1548-1557. [CrossRef]

81. Manshadi, M.D.; Navid, S.; Hoshino, Y.; Daneshi, E.; Noory, P.; Abbasi, M. The effects of human menstrual blood stem cells-derived granulosa cells on ovarian follicle formation in a rat model of premature ovarian failure. Microscopy Res. Techniquey 2019, 82, 635-642. [CrossRef] 
82. Liebermann, D.A.; Tront, J.S.; Sha, X.; Mukherjee, K.; Mohamed-Hadley, A.; Hoffman, B. Gadd45 stress sensors in malignancy and leukemia. Crit. Rev. Oncog. 2011, 16, 129-140. [CrossRef] [PubMed]

83. Hyka-Nouspikel, N.; Desmarais, J.; Gokhale, P.J.; Jones, M.; Meuth, M.; Andrews, P.W.; Nouspikel, T. Deficient DNA damage response and cell cycle checkpoints lead to accumulation of point mutations in human embryonic stem cells. Stem Cells (Dayt. Ohio) 2012, 30, 1901-1910. [CrossRef] [PubMed]

84. Zhao, Y.; Lou, I.C.; Conolly, R.B. Computational modeling of signaling pathways mediating cell cycle checkpoint control and apoptotic responses to ionizing radiation-induced DNA damage. Dose-Response 2012, 10, 251-273. [CrossRef] [PubMed]

85. Yan, Z.; Guo, F.; Yuan, Q.; Shao, Y.; Zhang, Y.; Wang, H.; Hao, S.; Du, X. Endometrial mesenchymal stem cells isolated from menstrual blood repaired epirubicin-induced damage to human ovarian granulosa cells by inhibiting the expression of Gadd45b in cell cycle pathway. Stem Cell Res. Ther. 2019, 10, 4. [CrossRef] [PubMed]

86. Wang, Z.; Wang, Y.; Yang, T.; Li, J.; Yang, X. Study of the reparative effects of menstrual-derived stem cells on premature ovarian failure in mice. Stem Cell Res. Ther. 2017, 8, 11. [CrossRef]

87. Chan, R.W.; Ng, E.H.; Yeung, W.S. Identification of cells with colony-forming activity, self-renewal capacity, and multipotency in ovarian endometriosis. Am. J. Pathol. 2011, 178, 2832-2844. [CrossRef]

88. Kao, A.P.; Wang, K.H.; Chang, C.C.; Lee, J.N.; Long, C.Y.; Chen, H.S.; Tsai, C.F.; Hsieh, T.H.; Tsai, E.M. Comparative study of human eutopic and ectopic endometrial mesenchymal stem cells and the development of an in vivo endometriotic invasion model. Fertil. Steril. 2011, 95, 1308-1315. [CrossRef]

89. Zhang, S.; Li, P.; Yuan, Z.; Tan, J. Platelet-rich plasma improves therapeutic effects of menstrual blood-derived stromal cells in rat model of intrauterine adhesion. Stem Cell Res. Ther. 2019, 10, 61. [CrossRef]

90. Zheng, S.X.; Wang, J.; Wang, X.L.; Ali, A.; Wu, L.M.; Liu, Y.S. Feasibility analysis of treating severe intrauterine adhesions by transplanting menstrual blood-derived stem cells. Int. J. Mol. Med. 2018, 41, 2201-2212. [CrossRef]

91. Tan, J.; Li, P.; Wang, Q.; Li, Y.; Li, X.; Zhao, D.; Xu, X.; Kong, L. Autologous menstrual blood-derived stromal cells transplantation for severe Asherman's syndrome. Hum. Reprod. (Oxf. Engl.) 2016, 31, 2723-2729. [CrossRef]

92. Domnina, A.; Novikova, P.; Obidina, J.; Fridlyanskaya, I.; Alekseenko, L.; Kozhukharova, I.; Lyublinskaya, O.; Zenin, V.; Nikolsky, N. Human mesenchymal stem cells in spheroids improve fertility in model animals with damaged endometrium. Stem Cell Res. Ther. 2018, 9, 50. [CrossRef] [PubMed]

93. Paduano, F.; Marrelli, M.; Palmieri, F.; Tatullo, M. CD146 Expression Influences Periapical Cyst Mesenchymal Stem Cell Properties. Stem Cell Rev. Rep. 2016, 12, 592-603. [CrossRef] [PubMed]

94. Nagamura-Inoue, T.; He, H. Umbilical cord-derived mesenchymal stem cells: Their advantages and potential clinical utility. World J. Stem Cells 2014, 6, 195-202. [CrossRef] [PubMed]

95. Yu, Y.B.; Song, Y.; Chen, Y.; Zhang, F.; Qi, F.Z. Differentiation of umbilical cord mesenchymal stem cells into hepatocytes in comparison with bone marrow mesenchymal stem cells. Mol. Med. Rep. 2018, 18, 2009-2016. [CrossRef]

96. Qiu, Y.; Yun, M.M.; Han, X.; Zhao, R.; Zhou, E.; Yun, S. Human umbilical cord mesenchymal stromal cells suppress MHC class II expression on rat vascular endothelium and prolong survival time of cardiac allograft. Int. J. Clin. Exp. Med. 2014, 7, 1760-1767.

97. Mohamed, S.A.; Shalaby, S.; Brakta, S.; Elam, L.; Elsharoud, A.; Al-Hendy, A. Umbilical Cord Blood Mesenchymal Stem Cells as an Infertility Treatment for Chemotherapy Induced Premature Ovarian Insufficiency. Biomedicines 2019, 7, 7. [CrossRef]

98. Song, D.; Zhong, Y.; Qian, C.; Zou, Q.; Ou, J.; Shi, Y.; Gao, L.; Wang, G.; Liu, Z.; Li, H. Human Umbilical Cord Mesenchymal Stem Cells Therapy in Cyclophosphamide-Induced Premature Ovarian Failure Rat Model. BioMed Res. Int. 2016, 2517514. [CrossRef]

99. Zhu, S.F.; Hu, H.B.; Xu, H.Y.; Fu, X.F.; Peng, D.X.; Su, W.Y.; He, Y.L. Human umbilical cord mesenchymal stem cell transplantation restores damaged ovaries. J. Cell. Mol. Med. 2015, 19, 2108-2117. [CrossRef]

100. Wang, S.; Yu, L.; Sun, M.; Mu, S.; Wang, C.; Wang, D.; Yao, Y. The therapeutic potential of umbilical cord mesenchymal stem cells in mice premature ovarian failure. BioMed Res. Int. 2013, 690491. [CrossRef]

101. Jalalie, L.; Rezaie, M.J.; Jalili, A.; Rezaee, M.A.; Vahabzadeh, Z.; Rahmani, M.R.; Karimipoor, M.; Hakhamaneshi, M.S. Distribution of the CM-Dil-Labeled Human Umbilical Cord Vein Mesenchymal 
Stem Cells Migrated to the Cyclophosphamide-Injured Ovaries in C57BL/6 Mice. Iran. Biomed. J. 2019, 23, 200-208. [CrossRef]

102. Elfayomy, A.K.; Almasry, S.M.; El-Tarhouny, S.A.; Eldomiaty, M.A. Human umbilical cord blood-mesenchymal stem cells transplantation renovates the ovarian surface epithelium in a rat model of premature ovarian failure: Possible direct and indirect effects. Tissue Cell 2016, 48, 370-382. [CrossRef] [PubMed]

103. Ding, L.; Yan, G.; Wang, B.; Xu, L.; Gu, Y.; Ru, T.; Cui, X.; Lei, L.; Liu, J.; Sheng, X. Transplantation of UC-MSCs on collagen scaffold activates follicles in dormant ovaries of POF patients with long history of infertility. Sci. China. Life Sci. 2018, 61, 1554-1565. [CrossRef] [PubMed]

104. Yang, Y.; Lei, L.; Wang, S.; Sheng, X.; Yan, G.; Xu, L.; Liu, J.; Liu, M.; Zhen, X.; Ding, L. Transplantation of umbilical cord-derived mesenchymal stem cells on a collagen scaffold improves ovarian function in a premature ovarian failure model of mice. Vitr. Cell. Dev. Biology. Anim. 2019, 55, 302-311. [CrossRef] [PubMed]

105. Li, J.; Mao, Q.; He, J.; She, H.; Zhang, Z.; Yin, C. Human umbilical cord mesenchymal stem cells improve the reserve function of perimenopausal ovary via a paracrine mechanism. Stem Cell Res. Ther. 2017, 8, 55. [CrossRef] [PubMed]

106. Yang, X.; Zhang, M.; Zhang, Y.; Li, W.; Yang, B. Mesenchymal stem cells derived from Wharton jelly of the human umbilical cord ameliorate damage to human endometrial stromal cells. Fertil. Steril. 2011, 96, 1029-1036. [CrossRef]

107. Fan, D.; Wu, S.; Ye, S.; Wang, W.; Guo, X.; Liu, Z. Umbilical cord mesenchyme stem cell local intramuscular injection for treatment of uterine niche: Protocol for a prospective, randomized, double-blinded, placebo-controlled clinical trial. Medicine 2017, 96, e8480. [CrossRef]

108. Shi, Q.; Gao, J.; Jiang, Y.; Sun, B.; Lu, W.; Su, M.; Xu, Y.; Yang, X.; Zhang, Y. Differentiation of human umbilical cord Wharton's jelly-derived mesenchymal stem cells into endometrial cells. Stem Cell Res. Ther. 2017, 8, 246. [CrossRef]

109. Zhang, L.; Li, Y.; Guan, C.Y.; Tian, S.; Lv, X.D.; Li, J.H.; Ma, X.; Xia, H.F. Therapeutic effect of human umbilical cord-derived mesenchymal stem cells on injured rat endometrium during its chronic phase. Stem Cell Res. Ther. 2018, 9, 36. [CrossRef]

110. Xin, L.; Lin, X.; Pan, Y.; Zheng, X.; Shi, L.; Zhang, Y.; Ma, L.; Gao, C.; Zhang, S. A collagen scaffold loaded with human umbilical cord-derived mesenchymal stem cells facilitates endometrial regeneration and restores fertility. Acta Biomater. 2019, 92, 160-171. [CrossRef]

111. Xu, L.; Ding, L.; Wang, L.; Cao, Y.; Zhu, H.; Lu, J.; Li, X.; Song, T.; Hu, Y.; Dai, J. Umbilical cord-derived mesenchymal stem cells on scaffolds facilitate collagen degradation via upregulation of MMP-9 in rat uterine scars. Stem Cell Res. Ther. 2017, 8, 84. [CrossRef]

112. Cao, Y.; Sun, H.; Zhu, H.; Zhu, X.; Tang, X.; Yan, G.; Wang, J.; Bai, D.; Wang, J.; Wang, L.; et al. Allogeneic cell therapy using umbilical cord MSCs on collagen scaffolds for patients with recurrent uterine adhesion: A phase I clinical trial. Stem Cell Res. Ther. 2018, 9, 192. [CrossRef] [PubMed]

113. Wang, L.L.; Yu, Y.; Guan, H.B.; Qiao, C. Effect of Human Umbilical Cord Mesenchymal Stem Cell Transplantation in a Rat Model of Preeclampsia. Reprod. Sci. (Thousand Oakscalif.) 2016, 23, 1058-1070. [CrossRef] [PubMed]

114. Fu, L.; Liu, Y.; Zhang, D.; Xie, J.; Guan, H.; Shang, T. Beneficial effect of human umbilical cord-derived mesenchymal stem cells on an endotoxin-induced rat model of preeclampsia. Exp. Ther. Med. 2015, 10, 1851-1856. [CrossRef]

115. Zhang, D.; Fu, L.; Wang, L.; Lin, L.; Yu, L.; Zhang, L.; Shang, T. Therapeutic benefit of mesenchymal stem cells in pregnant rats with angiotensin receptor agonistic autoantibody-induced hypertension: Implications for immunomodulation and cytoprotection. Hypertens. Pregnancy 2017, 36, 247-258. [CrossRef] [PubMed]

116. Huang, Y.; Wu, Y.; Chang, X.; Li, Y.; Wang, K.; Duan, T. Effects of Human Umbilical Cord Mesenchymal Stem Cells on Human Trophoblast Cell Functions In Vitro. Stem Cells Int. 2016, 9156731. [CrossRef] [PubMed]

117. Xiong, Z.H.; Wei, J.; Lu, M.Q.; Jin, M.Y.; Geng, H.L. Protective effect of human umbilical cord mesenchymal stem cell exosomes on preserving the morphology and angiogenesis of placenta in rats with preeclampsia. Biomed. Pharmacother. 2018, 105, 1240-1247. [CrossRef] [PubMed]

118. Loukogeorgakis, S.P.; De Coppi, P. Concise Review: Amniotic Fluid Stem Cells: The Known, the Unknown, and Potential Regenerative Medicine Applications. Stem Cells (Dayt. Ohio) 2017, 35, 1663-1673. [CrossRef] 
119. Steigman, S.A.; Ahmed, A.; Shanti, R.M.; Tuan, R.S.; Valim, C.; Fauza, D.O. Sternal repair with bone grafts engineered from amniotic mesenchymal stem cells. J. Pediatric Surg. 2009, 44, 1120-1126. [CrossRef]

120. Kunisaki, S.M.; Freedman, D.A.; Fauza, D.O. Fetal tracheal reconstruction with cartilaginous grafts engineered from mesenchymal amniocytes. J. Pediatric Surg. 2006, 41, 675-682. [CrossRef]

121. Kunisaki, S.M.; Fuchs, J.R.; Kaviani, A.; Oh, J.T.; LaVan, D.A.; Vacanti, J.P.; Wilson, J.M.; Fauza, D.O. Diaphragmatic repair through fetal tissue engineering: A comparison between mesenchymal amniocyteand myoblast-based constructs. J. Pediatric Surg. 2006, 41, 34-39. [CrossRef]

122. Fuchs, J.R.; Kaviani, A.; Oh, J.T.; LaVan, D.; Udagawa, T.; Jennings, R.W.; Wilson, J.M.; Fauza, D.O. Diaphragmatic reconstruction with autologous tendon engineered from mesenchymal amniocytes. J. Pediatric Surg. 2004, 39, 834-838. [CrossRef] [PubMed]

123. Xiao, G.Y.; Liu, I.H.; Cheng, C.C.; Chang, C.C.; Lee, Y.H.; Cheng, W.T.; Wu, S.C. Amniotic fluid stem cells prevent follicle atresia and rescue fertility of mice with premature ovarian failure induced by chemotherapy. PLoS ONE 2014, 9, e106538. [CrossRef] [PubMed]

124. Liu, T.; Huang, Y.; Guo, L.; Cheng, W.; Zou, G. CD44+/CD105+ human amniotic fluid mesenchymal stem cells survive and proliferate in the ovary long-term in a mouse model of chemotherapy-induced premature ovarian failure. Int. J. Med Sci. 2012, 9, 592-602. [CrossRef] [PubMed]

125. Xiao, G.Y.; Cheng, C.C.; Chiang, Y.S.; Cheng, W.T.; Liu, I.H.; Wu, S.C. Exosomal miR-10a derived from amniotic fluid stem cells preserves ovarian follicles after chemotherapy. Sci. Rep. 2016, 6, 23120. [CrossRef] [PubMed]

126. Schickel, R.; Boyerinas, B.; Park, S.M.; Peter, M.E. MicroRNAs: Key players in the immune system, differentiation, tumorigenesis and cell death. Oncogene 2008, 27, 5959-5974. [CrossRef] [PubMed]

127. Feng, X.; Ling, L.; Zhang, W.; Liu, X.; Wang, Y.; Luo, Y.; Xiong, Z. Effects of Human Amnion-Derived Mesenchymal Stem Cell (hAD-MSC) Transplantation In Situ on Primary Ovarian Insufficiency in SD Rats. Reprod. Sci. (Thousand Oakscalif.) 2020, 27, 1502-1512. [CrossRef]

128. Ling, L.; Feng, X.; Wei, T.; Wang, Y.; Wang, Y.; Zhang, W.; He, L.; Wang, Z.; Zeng, Q.; Xiong, Z. Effects of low-intensity pulsed ultrasound (LIPUS)-pretreated human amnion-derived mesenchymal stem cell (hAD-MSC) transplantation on primary ovarian insufficiency in rats. Stem Cell Res. Ther. 2017, 8, 283. [CrossRef]

129. Hwang, J.H.; Lee, M.J.; Seok, O.S.; Paek, Y.C.; Cho, G.J.; Seol, H.J.; Lee, J.K.; Oh, M.J. Cytokine expression in placenta-derived mesenchymal stem cells in patients with pre-eclampsia and normal pregnancies. Cytokine 2010, 49, 95-101. [CrossRef]

130. Yin, N.; Zhao, W.; Luo, Q.; Yuan, W.; Luan, X.; Zhang, H. Restoring Ovarian Function With Human Placenta-Derived Mesenchymal Stem Cells in Autoimmune-Induced Premature Ovarian Failure Mice Mediated by Treg Cells and Associated Cytokines. Reprod. Sci. (Thousand Oakscalif.) 2018, 25, 1073-1082. [CrossRef]

131. Zhang, H.; Luo, Q.; Lu, X.; Yin, N.; Zhou, D.; Zhang, L.; Zhao, W.; Wang, D.; Du, P.; Hou, Y. Effects of hPMSCs on granulosa cell apoptosis and AMH expression and their role in the restoration of ovary function in premature ovarian failure mice. Stem Cell Res. Ther. 2018, 9, 20. [CrossRef]

132. Yin, N.; Wang, Y.; Lu, X.; Liu, R.; Zhang, L.; Zhao, W.; Yuan, W.; Luo, Q.; Wu, H.; Luan, X.; et al. hPMSC transplantation restoring ovarian function in premature ovarian failure mice is associated with change of Th17/Tc17 and Th17/Treg cell ratios through the PI3K/Akt signal pathway. Stem Cell Res. Ther. 2018, 9, 37. [CrossRef] [PubMed]

133. Li, H.; Zhao, W.; Wang, L.; Luo, Q.; Yin, N.; Lu, X.; Hou, Y.; Cui, J.; Zhang, H. Human placenta-derived mesenchymal stem cells inhibit apoptosis of granulosa cells induced by IRE1 $\alpha$ pathway in autoimmune POF mice. Cell Biol. Int. 2019, 43, 899-909. [CrossRef] [PubMed]

134. Kim, T.H.; Choi, J.H.; Jun, Y.; Lim, S.M.; Park, S.L.; Paek, J.Y.L.; Lee, S.H.; Hwang, J.Y.; Kim, G.J. 3D-cultured human placenta-derived mesenchymal stem cell spheroids enhance ovary function by inducing folliculogenesis. Sci. Rep. 2018, 8, 15313. [CrossRef] [PubMed]

135. Chen, C.P. Placental villous mesenchymal cells trigger trophoblast invasion. Cell Adhes. Migr. 2014, 8, 94-97. [CrossRef] [PubMed]

136. Rolfo, A.; Giuffrida, D.; Nuzzo, A.M.; Pierobon, D.; Cardaropoli, S.; Piccoli, E.; Giovarelli, M.; Todros, T. Pro-inflammatory profile of preeclamptic placental mesenchymal stromal cells: New insights into the etiopathogenesis of preeclampsia. PLoS ONE 2013, 8, e59403. [CrossRef] [PubMed] 
137. Chen, C.P.; Huang, J.P.; Chu, T.Y.; Aplin, J.D.; Chen, C.Y.; Wu, Y.H. Human placental multipotent mesenchymal stromal cells modulate trophoblast migration via Rap1 activation. Placenta 2013, 34, 913-923. [CrossRef]

138. Nuzzo, A.M.; Giuffrida, D.; Zenerino, C.; Piazzese, A.; Olearo, E.; Todros, T.; Rolfo, A. JunB/cyclin-D1 imbalance in placental mesenchymal stromal cells derived from preeclamptic pregnancies with fetal-placental compromise. Placenta 2014, 35, 483-490. [CrossRef]

139. Qu, H.M.; Qu, L.P.; Pan, X.Z.; Mu, L.S. Upregulated miR-222 targets BCL2L11 and promotes apoptosis of mesenchymal stem cells in preeclampsia patients in response to severe hypoxia. Int. J. Clin. Exp. Pathol. 2018, 11, 110-119.

140. Nuzzo, A.M.; Giuffrida, D.; Masturzo, B.; Mele, P.; Piccoli, E.; Eva, C.; Todros, T.; Rolfo, A. Altered expression of G1/S phase cell cycle regulators in placental mesenchymal stromal cells derived from preeclamptic pregnancies with fetal-placental compromise. Cell Cycle (Georget. Tex.) 2017, 16, 200-212. [CrossRef]

141. Lian, Q.; Zhang, Y.; Zhang, J.; Zhang, H.K.; Wu, X.; Zhang, Y.; Lam, F.F.; Kang, S.; Xia, J.C.; Lai, W.H. Functional mesenchymal stem cells derived from human induced pluripotent stem cells attenuate limb ischemia in mice. Circulation 2010, 121, 1113-1123. [CrossRef]

142. Zhang, J.; Chan, Y.C.; Ho, J.C.; Siu, C.W.; Lian, Q.; Tse, H.F. Regulation of cell proliferation of human induced pluripotent stem cell-derived mesenchymal stem cells via ether-à-go-go 1 (hEAG1) potassium channel. Am. J. Physiol. Cell Physiol. 2012, 303, C115-C125. [CrossRef] [PubMed]

143. Peng, K.Y.; Lee, Y.W.; Hsu, P.J.; Wang, H.H.; Wang, Y.; Liou, J.Y.; Hsu, S.H.; Wu, K.K.; Yen, B.L. Human pluripotent stem cell (PSC)-derived mesenchymal stem cells (MSCs) show potent neurogenic capacity which is enhanced with cytoskeletal rearrangement. Oncotarget 2016, 7, 43949-43959. [CrossRef] [PubMed]

144. Bloor, A.; Patel, A.; Griffin, J.E.; Gilleece, M.H.; Radia, R.; Yeung, D.T.; Drier, D.; Larson, L.S.; Uenishi, G.I.; Hei, D.; et al. Production, safety and efficacy of iPSC-derived mesenchymal stromal cells in acute steroid-resistant graft versus host disease: A phase I, multicenter, open-label, dose-escalation study. Nat. Med. 2020. [CrossRef] [PubMed]

(C) 2020 by the authors. Licensee MDPI, Basel, Switzerland. This article is an open access article distributed under the terms and conditions of the Creative Commons Attribution (CC BY) license (http://creativecommons.org/licenses/by/4.0/). 